\title{
Groza doświadczania. Sytuacja graniczna jako obrzęd przejścia w inicjacji dojrzałościowej na przykładzie sztuki dla młodzieży Pacamambo Wajdiego Mouawada
}

\section{Abstrakt:}

Artykuł stanowi studium sztuki kanadyjskiego pisarza Wajdiego Mouawada $\mathrm{Pa}$ camambo (2000), łączącej cechy dramatu inicjacyjnego z komponentami horroru i ukazującej koszmar dorastania poprzez nieoczekiwane zetknięcie ze śmiercią. Autorka wykazuje analogię pomiędzy strukturą obrzędu przejścia proponowaną przez Arnolda van Gennepa i pogłębioną przez Victora Turnera a aspektami związanymi z doświadczaniem siebie w sytuacji granicznej w ujęciu Karla Jaspersa oraz poetyką horroru. Na tej podstawie proponuje wyodrębnienie tragicznego modelu adolescencji (obok klasycznego - idyllicznego i romantycznego - cierpiącego), w którym rolę tradycyjnych obrzędów zastępuje doświadczenie graniczne. Wskazuje, że jest to model, z którym często możemy się spotkać we współczesnych dramatach dla młodzieży, a nawet w sztukach skierowanych do dzieci. Wyodrębnia także pojęcie dramatu inicjacyjnego, który wciąż pozostaje poza obszarem zainteresowań literaturoznawców.

Słowa kluczowe:

adolescencja, dramat dla młodzieży, dramat inicjacyjny, horror, obrzęd przejścia, Pacamambo, sytuacja graniczna, Wajdi Mouawad

\section{The Horror of Experiencing: A Limit Situation as a Rite of} Passage in Adolescent Initiation on the Example of Wajdi Mouawad's Young Adult Play Pacamambo

\section{Abstract:}

The article is a study of Pacamambo (2000), a play by Canadian writer Wajdi Mouawad, which combines the features of an initiation drama with horror elements

* Katarzyna Mazur-Lejman - mgr, przygotowuje rozprawę doktorską w Instytucie Literatury Polskiej Wydziału Polonistyki na Uniwersytecie Warszawskim dotyczącą inicjacji w dorosłość w dramaturgii dla niedorosłego odbiorcy. Kontakt: kamazur@protonmail.com. 
and shows the nightmare of growing up through unexpected encounters with death. The author shows an analogy between the structure of the rite of passage, proposed by Arnold van Gennep and deepened by Victor Turner, and the aspects related to experiencing oneself in a limit situation in terms of Karl Jaspers and to the poetics of horror. On this basis, she proposes to isolate the tragic model of adolescence (next to the classic - idyllic and romantic - suffering) in which the role of traditional rites is replaced by a limit experience. She indicates that this is a model that we can often come across in contemporary young adult dramas and even in plays for children. She also distinguishes the concept of initiation drama, which still remains outside the area of interest of literary scholars.

Key words:

adolescence, young adult drama, coming-of-age drama, horror, rite of passage, Pacamambo, limit situation, Wajdi Mouawad

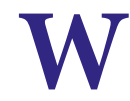
edług Mircei Eliadego (1959/1997) „wszelka inicjacja polega na symbolicznej śmierci, po której następują odrodzenie lub zmartwychwstanie” (s. 12), na umieraniu w jednym bycie, aby narodzić się w nowym, lepszym. Śmierć rozumiana jest tu jako ostateczny kres pewnego stanu. W przypadku inicjacji dojrzałościowej jest to kres dzieciństwa, któremu patronują wymowne figury - Eros, Tanatos i Prometeusz (Czyżak, 2003). Narodziny oznaczają więc osiągnięcie dorosłości, rozumianej jako wtajemniczenie w niedostępne dotąd obszary życia, poznanie miłości, śmierci lub poświęcenia, a w konsekwencji uzyskanie nowego statusu społecznego. W społeczeństwach pierwotnych inicjacji towarzyszyły obrzędy - zestandaryzowane i powtarzalne zachowania określone przez Arnolda van Gennepa (1909/2006) jako rytuały przejścia. Przypisywano im rolę „strażników ładu społecznego” mających niwelować niepożądane okoliczności związane z nadchodzącą zmianą egzystencjalną. Dziś to antropologiczne pojęcie, służące opisowi pierwotnych społeczeństw plemiennych $i$ ich mistycznych wtajemniczeń, często stosuje się jako narzędzie analityczne w innych dziedzinach naukowych. Zwraca się uwagę, że rytuały mogą mieć charakter świecki i jednostkowy, nie muszą się wiązać ze społecznym statusem, a ich materią może być „zmiana dokonująca się w człowieku” (Jaskulska, 2016, s. 46). Kategoria rite de passage znajduje zastosowanie w analizach współczesnych inicjacji dojrzałościowych m.in. na gruncie psychologii, pedagogiki, literaturoznawstwa i kulturoznawstwa. Szczególnie chętnie bada się za jej pomocą baśń. W znanym modelu bajki magicznej (Propp, 1928/2011) mamy do czynienia z powtarzającą się strukturą i schematycznym protagonistą, który poddawany jest licznym i trudnym próbom (taką postacią jest 
choćby Kopciuszek). W ich wyniku następuje dojrzewanie do nowej roli, zakończone zmianą statusu społecznego. Uważa się ponadto, że w dobie zaniku obrzędowości to opowieść może przejąć funkcję obrzędów inicjacyjnych (Leszczyński, 2006a) poprzez „budowanie zasobów osobistych” odbiorcy (Molicka, 2006, s. 117), a baśń uznaje się za „współczesną przestrzeń dojrzałościowych doświadczeń rytualnych" (Jaskulska, 2016, s. 45).

Uważam, że kategorię Gennepowskich rytuałów przejścia z powodzeniem można zastosować także w literaturoznawczej analizie współczesnej dramaturgii dla dzieci i młodzieży, zwłaszcza dramatu inicjacyjnego, rozumianego dwojako w niniejszym artykule (w analogii do definicji powieści inicjacyjnej) - jako dzieło, którego główną problematyką jest kwestia poznania, zdobycia wiedzy o sobie lub świecie poprzez hermetyczny proces wtajemniczenia (Illg, 1983), bądź też jako utwór o przekraczaniu granicy, umieraniu dla dzieciństwa (Baluch, 1998). Podobnie jak w przypadku baśni, analizując rytualne przejścia w dramacie, trzeba mieć na uwadze wewnątrztekstową sytuację bohatera literackiego oraz zewnątrztekstowy inicjacyjny charakter, jaki może mieć dany utwór dla odbiorcy (Leszczyński, 2006a). W przypadku dramatu jest to zagadnienie o tyle specyficzne, że niezwykle rzadko podlega on samodzielnej lekturze ${ }^{1}$, poznawany jest natomiast za pośrednictwem teatralnego spektaklu, który ma silnie liminalny (Turner, 1969/2010) charakter, co tym bardziej czynić może z dramatu przestrzeń rytualnych doświadczeń.

Dramat dla dzieci i młodzieży, tak jak współczesna proza dla niedorosłych czytelników, odchodzi od nostalgicznej wizji szczęśliwego dziecka w idyllicznym ogrodzie dzieciństwa oraz rezygnuje z misji dydaktyczno-wychowawczej. Jednocześnie coraz częściej widzi w dziecięcym odbiorcy pełnoprawnego mieszkańca świata, uczestnika życia, a tym samym czyni go partnerem w rozmowie (Bucholc, 2013). Oferuje mu zarówno pełnię artystycznych środków wyrazu, jak i problematykę poważną (przez dłuższy czas zarezerwowaną dla osób dorosłych), demaskującą tabu, kontrowersyjną, związaną ze śmiercią, przemocą, depresją, wojną oraz rozkładem rodziny. Marta Karasińska (2007) pisze o „nowym brutalizmie” jako ogólnej tendencji współczesnej dramaturgii dla dzieci i młodzieży. Na tym tle zaobserwować można także szczególnie rozwinięty nurt inicjacyjny - bohaterowie dramatu w odartej ze złudzeń, brutalnej rzeczywistości muszą uporać się z własnym dorastaniem, dookreślić tożsamość i odnaleźć swoje miejsce w świecie. Nierzadko są przy tym pozbawieni jakiegokolwiek przewodnictwa, wchodzą w dorosłość sami, na własną

1 Wskazuje na to np. szczegółowy raport Biblioteki Narodowej o stanie czytelnictwa w Polsce w 2017 roku (Koryś, Michalak, Zasacka, Chymkowski, 2018). 
rękę muszą stawiać czoła chaosowi i rozpadowi wartości. Samodzielnie odkrywają prawdę o świecie, pokonują strach przed nieznanym i przechodzą próby, którym poddaje ich los.

Na straży ładu nie stoi rytuał, jego miejsce zajmuje przeżycie sytuacji granicznej. Jest to, według Karla Jaspersa (1938/1978), taki splot okoliczności zewnętrznych, których jednostka, uświadomiwszy je sobie, nie może kreować ani zmieniać, gdyż stawiają jej one radykalny opór. W konsekwencji prowadzi to do silnego przeżycia egzystencjalnego, mogącego mieć wpływ na postrzeganie rzeczywistości. Wyróżnione przez tego autora przykłady sytuacji granicznych to: świadomość bycia stale $\mathrm{w}$ jakiejś sytuacji, cierpienie i śmierć (niezależne od człowieka) oraz walka i przyjęcie winy (mające związek z jego działaniem). Wykażę później, że sytuacja graniczna w swojej strukturze wpisuje się w naturę obrzędu przejścia i go zastępuje, tworząc swoiste „dzikie przejście”, pozbawione rezonerów, rytuałów i przygotowania. Rolę umownego obrzędu pełni tu rzeczywiste przeżycie, a samo przejście wyraźnie traci strukturalno-funkcjonalne znaczenie, przestaje być gwarantem społecznego porządku i staje się osobistym doświadczeniem jednostki (Jaskulska, 2013).

Obraz inicjacji wyłaniający się z takiego modelu nie jest już ani klasycznie idylliczny, ani nawet romantyczny, ukazujący młodość cierpiącą, ale znamiennie tragiczny - naznaczony traumą lub klęską. Bohater dramatu, będący podmiotem inicjacji, nie osiąga nowego statusu społecznego, nie zostaje wprowadzony do nowej wspólnoty, nie zostaje mu objawiona „nowa koncepcja świata” (Eliade, 1959/1997, s. 8). Jako przykład posłużyć może sztuka W beczce chowany Roberta Jarosza (2006). Próba dojrzałości, której zostaje poddany bohater, kończy się powrotem do beczki (symbolizującej zarówno matczyną macicę, jak i okres niedojrzałości, wychowania, uzależnienia od innych, dziecięcych lęków i bezsilności), skąd wypuszczono go, gdy osiągnął metrykalną dorosłość, ale ostatecznie nie sprostał jej wyzwaniom (Gromadzka, 2016). W Stopklatce Maliny Prześlugi (2011) nastoletni chłopak zostaje natomiast sparaliżowany w wyniku wykonania nierozważanego skoku do wody. Sytuacja graniczna, w której się znajduje, otwiera proces inicjacyjny. Bohater zyskuje niedostępną mu wcześniej wiedzę o naturze życia, ale traci wszystkie dotychczasowe osiągnięcia - stworzenie związku, uzyskanie samodzielności, wypracowaną perspektywę rozwoju; ponownie wymaga opieki matki i noszenia pieluch. Bohaterowie obu tych sztuk zostają uwięzieni w koszmarze dzieciństwa opozycyjnego do „sentymentalnego i naiwnego raju zaprzepaszczonego”, „w świecie upiornej baśni, skąd nie ma ucieczki" (Leszczyński, 2006b, s. 20). Ich inicjacja jest tragiczna, przynosi odwrotny od zamierzonego rezultat - bohater umiera dla jednego bytu, ale drugi, dla którego się rodzi, nie tylko nie jest lepszy, ale z wielu względów gorszy. 
W większości przypadków postaci dramatu inicjacyjnego przekraczają jednak „modalność dziecka” i doświadczają pełni człowieczeństwa, „innego sposobu istnienia, niedostępnego dla tych, którzy nie stawili czoła próbom inicjacyjnym, nie poznali śmierci" (Eliade, 1959/1997, s. 9), choć wciąż obraz ich dorastania daleki jest od arkadyjskiego. Wobec towarzyszącego inicjacji upadku starego porządku, rozkładu wszystkiego, co dotychczasowe i znane, bohater (nowicjusz) odczuwa niepewność i lęk. Jeśli zaś do zdefiniowania pojęcia grozy posłużymy się koncepcją Stephana Kinga (1995; za: Has-Tokarz, 2011, s. 49), według której ta właściwość „powstaje w wyniku uczucia powszechnej dezintegracji, wrażenia, że rzeczy wokół zaczynają się rozpadać", to horror stanie się elementem naturalnie wpisanym $\mathrm{w}$ cały proces przejścia, sytuując ów proces w obszarze koszmaru.

Wyrazistym przykładem tekstu dramatycznego uwypuklającego przerażające aspekty dojrzewania i ukazującego grozę przeżywania inicjacji w dorosłość jest Pacamambo, dzieło kanadyjskiego pisarza Wajdiego Mouawada (2000/2011), które stanowi przedmiot analizy w niniejszym artykule. Pragnę podkreślić, że trudno byłoby udowodnić, że pod względem gatunkowym ta sztuka jest horrorem, jeśli w pewnym uproszczeniu przyjęlibyśmy, że „horror ma przede wszystkim przerażać" (Has-Tokarz, 2011, s. 52). Horror jako odmiana gatunkowa stosunkowo rzadko pojawia się w twórczości dramatycznej w ogóle, a już w szczególności w dramaturgii przeznaczonej dla dzieci i młodzieży (co zresztą zasługuje na osobne studium). Bez wątpienia jednak Pacamambo poprzez wykorzystanie wybranych elementów poetyki grozy wyraźnie wpisuje się w nurt „literatury strachu" (Papuzińska, 1996, s. 84). Nabiera to szczególnego znaczenia, jeśli weźmie się pod uwagę fakt, że dzieło jest jednocześnie dramatem inicjacyjnym.

Julia, pierwszoplanowa bohaterka utworu, odkrywa tajemnicę istnienia poprzez doświadczenie i poznanie śmierci w czasie samotnego dziewiętnastodniowego czuwania przy rozkładającym się ciele zmarłej babci. Dziewczynka przechodzi przez proces inicjacji w sposób nietypowy dla plemiennych nowicjuszy, których ponowne narodziny odbywały się w ustalonych społecznie ramach symbolicznych zachowań, ale znamienny dla współczesnych bohaterów dramatycznych - nieoczekiwany, przypadkowy, bez przygotowania i bez przyzwolenia społeczności, tj. poprzez przeżycie wspomnianej wcześniej sytuacji granicznej. Jeśli przyjrzymy się strukturze obrzędu przejścia proponowanej przez van Gennepa (1909/2006), a pogłębionej przez Victora Turnera (1969/2010; zob. także Jaskulska, 2013), i aspektom związanym z doświadczaniem siebie w sytuacji granicznej w ujęciu Jaspersa (1938/1978; zob. także Rozmarynowska, 2012) oraz weźmiemy pod uwagę wybrane differentias specificas poetyki horroru (Has-Tokarz, 2011), dostrzeżemy pomiędzy nimi wiele 
punktów wspólnych, czyniących ze spania „u stóp trupa babci, który był w stanie poważnego rozkładu” (Mouawad, 2000/2011, s. 10), koszmarny rytuał dojrzałościowy bohaterki Pacamambo.

Julia wraz ze swoim psem, Grubasem, spędza noc w domu babci i staje się świadkiem jej niespodziewanej śmierci. Choć przebieg wydarzeń poznajemy poprzez retrospektywną rozmowę dziewczynki z psychiatrą, większość z nich zostaje ukazana odbiorcy w sposób bezpośredni. W scenie przedstawiającej umieranie kobiety autor posługuje się „treściami i rekwizytornią, które wzbudzają silne emocje, w tym przerażenie” (Has-Tokarz, 2011, s. 51). Rozpoczyna się ona od didaskaliów, wywołujących wrażenia wizualne ${ }^{2}$, wykorzystane zostają też archetypiczne motywy ciemności i nocy. Czytamy: „Noc. Ciemność. Można ujrzeć starą kobietę śpiącą w łóżku. Księżyc wchodzi przez okno i oświetla pokój” (Mouawad, 2000/2011, s. 11). W tym świetle dostrzec można również śpiącego psa i drzemiącą w fotelu dziewczynkę. Mouawad opisuje także towarzyszące temu obrazowi wrażenie akustyczne - jest to tykanie zegara, które zostaje przerwane wtargnięciem Księżyca do pokoju: „Zegar »tika«, ale nie »taka«. Zatrzymał się” (s. 11). To zatrzymanie jest znamienne dla wszelkich inicjacji - nastaje czas przejściowy. W przytoczonym fragmencie stary, naturalny porządek zostaje zaburzony przez pojawienie się fantastycznej postaci uosobionego Księżyca, którą - jak sugeruje warczenie psa - można identyfikować jako antagonistę. Nowy ład jeszcze się nie ukonstytuował. Szok poznawczy związany z wtargnięciem do świata, który wcześniej rządził się ustalonymi prawami, zjawiska spoza tej rzeczywistości (potwora), a także poetyka ciemności i nocy, to także elementy charakterystyczne dla literatury grozy (Knap, 2008).

Warto zwrócić uwagę również na przestrzeń, w której rozgrywa się akcja - nie jest to teren mistyczny, specjalnie przeznaczony dla obrzędów, ale zwykły dom, pokój pełen „mebli babci” (Mouawad, 2000/2011, s. 11). Has-Tokarz (2011) analizując kategorię przestrzeni grozy, sporo miejsca poświęca domowi jako miejscu, które w horrorze traci swe pozytywne konotacje: „Groza, od której dom w założeniu powinien chronić, ma swe źródło właśnie w nim” (s. 197). Tak jest i w omawianym przypadku: meble w pokoju „zaczynają się ruszać, wznoszą się, zaczynają latać", a okno samoistnie otwiera się, umożliwiając Księżycowi uprowadzenie staruszki (Mouawad, 2000/2011, s. 13). Wśród ciemności

2 Analizuję dramat wyłącznie z perspektywy literackiej teorii dramatu, mówiąc zatem o jego warstwie wizualnej, będę odnosić się jedynie do wewnątrztekstowego kształtu spektaklu, to jest do wizji scenicznej opisanej przez autora w didaskaliach. Poszczególne realizacje, sposób adaptacji i interpretacje reżyserskie wymagają innego instrumentarium badawczego i należą do osobnej dziedziny. 
rozproszonej tylko bladym księżycowym światłem, wśród unoszących się w powietrzu sprzętów, w domu niedającym schronienia, rodzi się groza. „Boję się” - mówi Maria-Maria, kobieta, po którą przyszedł Księżyc, a Grubas zaczyna skomleć, „próbuje ukryć się pod fotelem, ale fotel unosi się” (s. 12). Intruz żąda od Marii-Marii wydania ostatniego tchnienia. Julia wciąż śpi, jeszcze aktywnie nie uczestniczy w akcji, nie jest świadoma tego, co się dzieje. Są to zatem zabiegi lękotwórcze skierowane w stronę odbiorców. To oni, będąc naocznymi świadkami wydarzeń, mają odczuwać przerażenie, gdyż jak mówi antagonista: „Wszyscy się boją, gdy znajdują się twarzą w twarz z Księżycem” (s. 12).

Tuż przed śmiercią starsza kobieta wyrywa dziewczynkę ze snu. Ma to wymiar symboliczny: wszystko, co wydarzy się później, będzie nosić znamiona przebudzenia duchowego. Maria-Maria, tak jak przedstawiciele starszyzny w inicjacjach plemiennych, wzywa będące pod jej opieką dziecko do inicjacji, mówiąc: „Musisz być teraz duża, Julio” (s. 15). Inicjacja dziewczynki rozpoczyna się zatem, jak każda inicjacja dojrzałościowa, „aktem przerwania” (Eliade, 1959/1997, s. 18). Związane z fazą preliminalną wyłączenie, czyli pozbawienie statusu, odłączenie nowicjusza od dotychczasowej grupy, w czasie obrzędu inicjacji odbywa się zazwyczaj symbolicznie poprzez czasowe fizyczne oddzielenie od matki lub jakiś rodzaj oznaczenia - rytualne okaleczenie, obcięcie włosów czy założenie specjalnego ubioru. W przypadku doświadczenia sytuacji granicznej również mamy do czynienia $\mathrm{z}$ wyłączeniem, jednak traci ono wymiar symboliczny i staje się autentycznym doświadczeniem jednostki. Tak też jest w przypadku Julii. Dziewczynka spędza z umarłą babcią całą noc, a kiedy wstaje dzień i słońce rzuca światło na martwe oblicze kobiety, młoda bohaterka decyduje się zawlec ciało do piwnicy i dalej czuwać przy nim w ciemnościach. Zanim zostaje odnaleziona, mija dziewiętnaście dni, podczas których nie kontaktuje się ze światem i właściwie nie opuszcza swojego stanowiska. Oczekuje wtedy na spotkanie śmierci. Jak nowicjusz jest zatem izolowana, wyłączona, odseparowana od rodziców i innych ludzi. Ponadto sama siebie swoiście oznacza: „Od kiedy babcia umarła - mówi - zdecydowałam, że nie mam już tego samego koloru skóry” (Mouawad, 2000/2011, s. 23). W innym miejscu dodaje: „A pod bielą mojej białej skóry ujrzałam czarną skórę gniewu. Moja skóra stała się nagle czarna jak otchłań” (s. 27)3. Zarówno inicjacja, jak i sytuacja

3 Charakter tego oznaczenia jest także antyrasistowskim manifestem Julii, symbolizuje jej niezgodę na zło, w definicji którego mieści się zarówno śmierć, jak i nieludzkie traktowanie człowieka, np. ze względu na jego pochodzenie. Autor w posłowiu sztuki deklaruje, że bunt i złość Julii były inspirowane wojną w Libanie (Mouawad, 2000/2011, s. 50). Wydaje mi się to jednak wątkiem pobocznym i wymagającym osobnej analizy. 
graniczna wiążą się z dezintegracją tego, co znane. Inicjacja to rozpad porządku świata i rządzących nim reguł, przejście spod opieki matki pod kuratelę ojca, wygaśnięcie wcześniejszych praw czy obowiązków. Doświadczenie graniczne zaś może stać się przyczyną zwątpienia w istnienie dobra i podważać poczucie własnej sprawczości. Z jednej strony więc rzeczywistość Julii zmienia się, gdyż babcia, dotąd stale obecna, odchodzi na zawsze, z drugiej - rzeczy do tej pory istotne tracą na wartości. Zabawa okazuje się niemożliwa. Zostaje zaburzone bezpieczeństwo istnienia, pojawia się poczucie bezradności. Julia mówi do psa: „A jutro będzie bez znaczenia, bo jutro możesz umrzeć [...]. A jeśli to ja umrę, jeśli jutro umrę, jeśli jutro księżyc wejdzie przez okno i mi powie: do góry, Julio, wstań. Twoja kolej by przejść przez okno - co byś zrobił, co? Możesz mi powiedzieć? Nic byś nie zrobił” (Mouawad, 2000/2011, s. 19).

Rozpada się więc cały dotychczasowy świat Julii, co znajduje symboliczne odzwierciedlenie we wzmagającym atmosferę grozy wizerunku rozkładu martwego ciała, w opisach przykrych doznań olfaktorycznych towarzyszących gniciu, we fragmentach dotyczących wręcz zobrazowanych obrzydliwości. Są to znów elementy zaczerpnięte z rekwizytorni horroru, który „admiruje ponad wszystko ikonografię śmierci, choroby, dematerializacji, biologicznego rozkładu, zarazy itp." (Has-Tokarz, 2011, s. 223). Julia uwspólnia z odbiorcą swoje doświadczenia poprzez dokładny opis wyglądu martwego ciała. Nazywa je bez ogródek trupem, określa jego pozycję, sugerującą, że w istocie Maria-Maria wcale nie siłowała się z Księżycem ani nie przechodziła przez okno. Metaforykę umierania zastępuje bezwzględny naturalizm śmierci. „Spójrz” - mówi Julia do psa. „Spójrz na Marię-Marię. Już się nie rusza. Nie oddycha. Już nie mówi. Zobacz, z czym zostajemy. Zobacz, co dostaliśmy: trupa na plecach" (Mouawad, 2000/2011, s. 20). Dziewczynka podkreśla przedmiotowość zmarłej osoby: „Duża rzecz, jak duży kostium [...]. Maria-Maria odeszła z duszą pod pachą. Naga, naprawdę naga, bo nie zabrała kostiumu. Jej jedyny i prawdziwy kostium zostawiła nam” (s. 20). Julia musi się uporać z jego obecnością zupełnie niemetaforycznie: „A potem zaczęłam ciągnąć Marię-Marię na kocu aż na klatkę schodową i zjechałam windą, bo schodami nie dałabym rady, była za ciężka” (s. 33).

W tekst sztuki wpisane jest założenie o rzeczywistym, fizycznym istnieniu martwego ciała - istnieniu dostępnym percepcji odbiorcy nie tylko poprzez poznanie opisu. Świadczą o tym i słowa dziewczynki, i didaskalia, niepozostawiające wątpliwości co do dosłownej obecności szczątków w wizualnej warstwie utworu. Mouawad (2000/2011) pisze wprost: „Jej trup leży na łóżku” (s. 28). Owo ciało staje się także przedmiotem zabiegów wykonywanych przez Julię, takich jak robienie makijażu czy zamykanie oczu. W sztuce nie brak też odniesień do biologicznych procesów rozkładu - bohaterka wyznaje psychiatrze, że 
„Maria-Maria z dnia na dzień zaczynała cuchnąć coraz bardziej” (s. 35); dowiadujemy się, że „stawała się coraz brzydsza i brzydsza” (s. 39). Eksponowanie fetoru gnijącego ciała, narastającego wraz z przebiegiem akcji do stanu, w którym „był tylko smród, a potem jeszcze ciemność” (s. 39), ma wywołać w odbiorcy poczucie niesmaku, wstrętu, obrzydzenia, a więc wszystkiego, co składa się na grozę rozkładu i wywołuje lęk przed śmiercią: „Zgroza, jaką śmierć w nas budzi, jest najsilniejszą ludzką reakcją nie tylko dlatego, że śmierć człowieka unicestwia, ale też dlatego, że wiąże się ze zgnilizną, z wydaniem martwego ciała na pastwę fermentacji” (Bataille, 1999; za: Has-Tokarz, 2011, s. 224).

Konsekwencją odejścia od tego, co znane, jest znalezienie się poza normą. Turner (1982/2005) zaznacza, że w fazie liminalnej jednostki znajdują się „poza normatywną strukturą społeczną" (s. 11), podobnie „w sytuacjach granicznych normy znane $\mathrm{z}$ codziennego doświadczenia przestają służyć człowiekowi za regulatory postępowania" (Rozmarynowska, 2012, s. 168). Należy zatem wypracować nowe zasady i rozwiązania. Julia podejmuje więc działanie, będące zupełnie poza normą społecznych zachowań, a nawet poza potocznie rozumianą normalnością. Ukryta z martwą babcią w piwnicy, maluje jej twarz i perfumami stara się stłumić zapach rozkładu. W ten sposób chce nabrać śmierć, że życie jeszcze nie odeszło, i zmusić ją do ponownych odwiedzin, a następnie do wytłumaczenia się ze swoich czynów. W rozmowie z psychiatrą, podczas której poznajemy Julię i - retrospektywnie - wydarzenia z czasu jej niezwykłego czuwania przy zmarłej, lekarz mówi wprost: „Zgadzasz się, że to, co zrobiłaś, nie jest normalne? Że takich rzeczy się nie robi?”, a na pytanie dziewczynki, dlaczego tak się nie robi, odpowiada: „Bo umarli, to umarli, a żyjący, to żyjący. Ten, kto żyje z umarłym, nie jest normalny" (Mouawad, 2000/2011, s. 38). Poza normą jest także przestrzeń, w której przebywa bohaterka. Są to podkreślające atmosferę niepokoju ciemne i klaustrofobiczne podziemia budynku.

Osamotnienie jednostki to kolejna wspólna cecha inicjacji, granicznego przeżycia i horroru. Rozmarynowska (2012) pisze, że w sytuacji granicznej „człowiek jest sam, ponieważ nikt nie może go zastąpić w jego decyzji. Odpowiedzialność ciąży jedynie na nim i z nikim nie może jej dzielić” (s. 175). Podobnie osamotnieni są członkowie communitas, Turner (1982/2005) podkreśla, że choć pozornie są razem, łączy ich jedynie to, że wszyscy biorą udział w rytuale - jednak dorosłość każdy z nich musi osiągnąć sam. Julia także, mimo obecności psa, którego szczekania „i tak nie rozumie” (Mouawad, 2000/2011, s. 19), musi sama dokonać wewnętrznej przemiany. Jest to rzecz, której się nie da uwspólnić: „Nikt nie umie sobie wyobrazić, co się stało w moim sercu, w mojej głowie. Przede wszystkim w mojej głowie. Nikt nic nie wie" - zaznacza dziewczynka na samym początku sztuki (s. 7). Samotność to również element 
wywołujący strach, w horrorze bohater samotnie mierzy się z niebezpieczeństwem, a jego lęk wzmożony jest tym, że nie ma go kto ukoić.

Typowe dla inicjacji jest poddawanie nowicjuszy rozmaitym próbom, którym muszą sprostać, aby udowodnić gotowość na zmianę, bycie godnym poznania tego, co tajemne. Julia pragnie dowieść, że jest mocniejsza od śmierci oraz ma dość siły, aby stawić jej czoła i pokonać strach. Podczas rozmowy z psychiatrą dziewczynka wspomina pierwszy poranek po wizycie Księżyca: „No i przez okno wpadło światło [...]. I nagle wszędzie było słońce. A jeszcze więcej go było na twarzy Marii-Marii. Rozjaśniło ją bezlitośnie. Do zieleni, do chłodu i samotności. Miała tylko słońce na twarzy. To była Śmierć, która chciała mnie przestraszyć" (Mouawad, 2000/2011, s. 33). Wszystkie działania Julii - ukrycie się w piwnicy, malowanie coraz bledszej twarzy i perfumowanie ciała kobiety, kiedy woń rozkładu staje się trudna do zniesienia - są próbą odparcia strachu. „Ona myśli, że nas tym przestraszy” - mówi bohaterka do psa, ale za chwilę stwierdza: „Śmierć nas nie dosięgnie [...]. Jesteśmy silniejsi od niej” (s. 35). „Gdybym mogła, powiedziałabym, jej, że jest bardzo odważna” (s. 42) - komentuje słyszana tylko przez widza, zauważana tylko przez odbiorcę martwa Maria-Maria. Ostateczna próba odwagi przychodzi jednak wtedy, gdy Julia decyduje się zrobić jedyną rzecz, której naprawdę się bała - zamknąć dotąd otwarte oczy babci i tym samym na zawsze się z nią pożegnać. Tuż po tym Śmierć we własnej osobie przychodzi objawić dziewczynce wiedzę tajemną, prawdę, którą Eliade (1959/1997) nazywa „koncepcją świata”. Próba kończy się zwycięstwem Julii, która udowadnia, że jest godna dostąpienia tajemnicy istnienia. W czasie rozmowy ze Śmiercią zostaje ustalony nowy porządek: „Jeśli zgadzasz się na narodziny, to zgadzasz się i na śmierć. Takie są reguły tej gry" (Mouawad, 2000/2011, s. 47).

W sytuacjach granicznych próbie zostają poddane wyznawane wartości, spośród których ocaleją tylko niektóre; często tego testu nie przechodzą poglądy i przekonania „uznawane dotąd za oczywiste” (Rozmarynowska, 2011, s. 168). W przypadku Julii wśród nich znalazło się zaufanie do struktur społecznych. Zapytana, dlaczego w momencie śmierci babci nie zadzwoniła na policję, tylko czekała na niemożliwe spotkanie ze śmiercią, odpowiada: „[...] jeśli pan nie wierzy $\mathrm{w}$ spotkanie śmierci, to ja tym bardziej nie wierzę w pomoc policjanta w takim momencie" (Mouawad, 2000/2011, s. 26). Będąc w stanie zawieszenia, kryzysu egzystencji, pomiędzy dwoma biegunami, jakimi są życie i śmierć, Julia wiedziała, że nie może oczekiwać pomocy ani zrozumienia ze strony społeczności, której częścią już nie była. Wartością, która zwycięsko przechodzi tu przez próbę, okazuje się natomiast samo życie. W dramacie uosabia je pies, Grubas, który tkwi w piwnicy razem z dziewczynką. Bohaterka mówi: „Myślę, że bez mojego psa 
i ja bym umarła. Ale on był ze mną [...], był żywy. Zasypiałam z głową na nim, żeby słyszeć bicie jego serca. Mówiłam do siebie »życie«" (s. 40). To właśnie uznanie życia za wartość nadrzędną, sprawdzoną w próbie, pozwoliło Julii bez buntu przyjąć regułę zaproponowaną przez Śmierć.

Porządek egzystencjalny zmienia się zarówno w wyniku przeżycia przez jednostkę sytuacji granicznej, jak i przejścia rytuału adolescencyjnego. W ostatniej fazie inicjacji następuje włączenie do nowej grupy i zmiana statusu społecznego. Julia także wraca do społeczeństwa, jednak nie w chwili odnalezienia jej przez służby, ale kiedy po okresie milczenia decyduje się otworzyć przed psychiatrą i podzielić doświadczeniem wykraczającym poza empirię dziecka - wiedzą, której psychiatra nie śmie zakwestionować. W przypadku przeżycia granicznego zmiana egzystencjalna nie musi mieć wymiaru społecznego, ale dotyczy indywidualnych przeżyć jednostki, nowy staje się nie status, a samopoznanie: „Wiedza o tym, jaki człowiek jest, dotąd niedostępna, często dopiero wtedy się odsłania” (Rozmarynowska, 2011, s. 176). „Dzisiaj wiem - mówi psychiatrze Julia - że jest ziemia, która nazywa się Pacamambo” (Mouawad, 2000/2011, s. 48). Tytułowa fantastyczna kraina, w której nie ma zła, staje się metaforą wiedzy życiowej, dojrzałości i pełni człowieczeństwa, będących teraz udziałem Julii, a niedostępnych dla wszystkich, którzy nie poznali śmierci.

Pacamambo to sztuka łącząca elementy dramatu inicjacyjnego oraz horroru. Autor, operując „czynnikami lękotwórczymi” (Has-Tokarz, 2011, s. 49), tworzy atmosferę grozy, która służyć może pogłębieniu refleksji egzystencjalnych, a tym samym mieć walory terapeutyczne (Urbańczyk, 2014). Odbiorca nie tylko przyswaja nowe schematy poznawcze poprzez towarzyszenie głównej bohaterce na drodze inicjacyjnej w charakterze świadka, lecz także wskutek przeżycia strachu (wywołanego takimi zabiegami lękotwórczymi jak ukazanie martwego ciała czy uosobionej śmierci) oswoić może własny lęk przed śmiercią, bowiem „nadanie abstrakcyjnemu lękowi konkretnych kształtów jest sprowadzeniem go do kategorii strachu i umożliwia w interpretacji psychologicznej przezwyciężenie go" (Gemra, 2001, s. 189). Odwołanie się do archetypicznych, pierwotnych lęków, do prawideł rządzących ludzką psychiką oraz poruszanie trudnych problemów i zastosowanie motywów wanitatywnych sytuuje tekst Mouawada w trzeciej ${ }^{4}$, proponowanej przez Joannę Papuzińską (1996), kate-

4 Papuzińska (1996) dokonuje typologii utworów grozy dla dzieci: do pierwszej grupy zalicza te dzieła, w których strach zostaje skompromitowany, ośmieszony; do drugiej, te, których celem jest doświadczenie strachu i jest on główną emocją przeżywaną przez bohatera utworu i czytelnika; trzecią grupę stanowią teksty „trudnych tematów”, oswajające lub analizujące archetypiczne lęki, np. lęk przed śmiercią (s. 84). 
gorii „literatury strachu” dla dzieci, a więc na antypodach wciąż popularnego trendu w literaturze dziecięcej - zabawy ze strachem i jego kompromitacji. Przede wszystkim jednak ten tekst jest symbolicznym i sugestywnym obrazem grozy dojrzewania poprzez przeżywanie doświadczeń, które przynoszą wiedzę egzystencjalną, gdy tragizmu inicjacji nie łagodzą tradycyjnie pojęte rytuały i przygotowania.

\section{Bibliografia}

Baluch, A. (1998). Powieść inicjacyjna (na przykładzie wybranych utworów). W: Czyta, nie czyta... (o dziecku literackim) (s. 91-99). Kraków: Wydawnictwo Edukacyjne.

Bucholc, G. (2013). Pełnoprawny widz. Teatr, 12. Pobrane z: http://www.teatr-pismo. $\mathrm{pl} /$ przeglad/662/pelnoprawny_widz/.

Czyżak, A. (2003). Modele inicjacji. Wobec wspólnoty - przeciw wspólnocie. W: W. Gutowski, E. Owczarz (red.), Z problemów prozy. Powieść inicjacyjna (s. 341-351). Toruń: Dom Wydawniczy Duet.

Eliade, M. (1997). Inicjacja, obrzędy, stowarzyszenia tajemne (K. Kocjan, tłum.). Kraków: Znak. (wyd. oryg. 1959).

Gemra, A. (2001). Doświadczenia grozy. Kilka słów o horrorze. Prace Literackie, 39, 183-194.

Gromadzka, B. (2016). O potrzebie mitu. W beczce chowany Roberta Jarosza w odbiorze gimnazjalistów. W: M. Wiśniewska, M. Wróblewski (red.), Teatr i dramat dla dzieci i młodzieży (s. 41-52). Toruń: WN UMK.

Has-Tokarz, A. (2011). Horror w literaturze wspótczesnej i filmie. Lublin: Wydawnictwo UMCS.

Illg, J. (1983). Konstrukcja postaci w powieściach inicjacyjnych Tadeusza Micińskiego. Pamiętnik Literacki, 74(3), 101-117.

Jaskulska, S. (2013). „Rytuał przejścia” jako kategoria analityczna. Przyczynek do dyskusji nad badaniem rytualnego oblicza rzeczywistości szkolnej. Studia Edukacyjne, 26, 79-97.

Jaskulska, S. (2016). Współczesne rytuały przejścia z dzieciństwa do dorosłości: baśń o Śpiącej Królewnie. W: A. Grabowska, M. Zaorska (red.), Bajka, baśń, legenda $i$ mit w naukowych opracowaniach (s. 45-56). Olsztyn: Katedra UNESCO UWM.

Jaspers, K. (1978). Sytuacje graniczne (M. Skwieciński, tłum.). W: R. Rudziński, Jaspers (s. 220-254). Warszawa: Wiedza Powszechna. (wyd. oryg. 1938).

Jarosz, R. (2006). W beczce chowany. Nowe Sztuki dla Dzieci i Młodzieży, 22, 197-250. Karasińska, M. (2007). Fotorealizm? Dozwolone od lat dziesięciu. W: M. Karasińska, G. Leszczyński (red.), Dziecko i teatr w przestrzeni kultury. Tom 2. Świat w teatrze (s. 32-49). Poznań: Centrum Sztuki Dziecka. 
Knap, J. (2008). Niesamowitość i groza w literaturze polskiej dwudziestolecia międzywojennego (rekonesans badawczy). Annales Universitatis Paedagogicae Cracoviensis. Studia Historicolitteraria, 8, 44-55.

Koryś, I., Michalak, D., Zasacka, Z., Chymkowski, R. (2018). Stan czytelnictwa w Polsce w 2017 roku. Warszawa: BN. Pobrane z: https://www.bn.org.pl/download/document/1535441771.pdf.

Kowalska, J. (1999). Obrzędy przejścia w rzeczywistości końca XX wieku. Wprowadzenie. Etnografia Polska, 43(1-2), 21-35.

Leszczyński, G. (2006a). Baśń: rytuał przejścia (rite de passage). W: G. Leszczyński (red.), Kulturowe konteksty baśni. Tom 2. W poszukiwaniu straconego królestwa (s. 41-68). Poznań: Centrum Sztuki Dziecka.

Leszczyński, G. (2006b). Kulturowy obraz dziecka i dzieciństwa w literaturze drugiej połowy XIX i w XX wieku. Wybrane problemy. Warszawa: Wydział Polonistyki UW.

Molicka, M. (2006). Psychologiczne aspekty aksjologii baśni. W: G. Leszczyński (red.), Kulturowe konteksty baśni. Tom 2. W poszukiwaniu straconego królestwa (s. 110122). Poznań: Centrum Sztuki Dziecka.

Mouawad, W. (2011). Pacamambo (K. Skorupski, tłum.). Nowe Sztuki dla Dzieci i Młodzieży, 31, 11-49. (wyd. oryg. 2000).

Papuzińska, J. (1996). Atelier strachu. W: Dziecko w świecie emocji literackich (s. 74-88). Warszawa: Wydawnictwo SBP.

Propp, W. (2011). Morfologia bajki magicznej (P. Rojek, tłum.). Kraków: Nomos. (wyd. oryg. 1928).

Prześluga, M. (2011). Stopklatka. Nowe Sztuki dla Dzieci i Młodzieży, 32, 221-241.

Rozmarynowska, K. (2012). Sytuacja graniczna jako moment doświadczenia siebie w ujęciu Karla Jaspersa. Studia Philosophiae Christianae, 48(3), 165-183.

Turner, V. (2005). Od rytuału do teatru. Powaga zabawy (M. Dziekan, J. Dziekan, tłum.). Warszawa: Volumen. (wyd. oryg. 1982).

Turner, V. (2010). Proces rytualny. Struktura i antystruktura (E. Dżurak, tłum., J. Tokarska-Bakir, wstęp). Warszawa: PIW. (wyd. oryg. 1969).

Urbańczyk, L. (2014). Horror dla dzieci - korzyści i zagrożenia. Prace literaturoznawcze, 2, 195-206.

van Gennep, A. (2006). Obrzędy przejścia. Systematyczne studium ceremonii (B. Biały, tłum.). Warszawa: PIW. (wyd. oryg. 1909). 